\title{
PENEGAKAN HUKUM DALAM PEMILIHAN UMUM
}

\author{
Sukawati Lanang P Perbawa
}

\author{
Universitas Mahasaraswati Denpasar \\ sukawatilanang@gmail.com
}

\begin{abstract}
ABSTRAK
Ukuran keberhasilan Negara demokratis salah satunya dilihat dari kesuksesannya menyelenggarakan pemilu dan penegakan hukumnya. Perjalanan penegakan hokum dibidang pemilu mengalami perubahan dalam setiap pemilu baik pemilu legeslatif, pilpres dan pilkada. Untuk pemilu saat ini, dalam menindaklanjuti tindak pidana pemilu, ternyata dan tidak hanya cara kerja yang berbeda, namun terdapat wadah koordinasi yang berbeda dibandingkan tindak pidana umum. Dalam Undang-Undang Nomor 7 Tahun 2017 telah diatur bahwa ada 4 (empat) institusi yang terlibat dalam penanganan perkara tindak pidana pemilu yakni Panitia Pengawas Pemilu (Panwaslu),Kepolisian, Kejaksaan, dan Pengadilan. Untuk mengefektifkan penanganan perkara pelanggaran pemilu yang menyangkut pidana maka Panwaslu, Kepolisian, dan Kejaksaan membentuk Sentra Penegakan Hukum Terpadu (Sentra Gakkumdu).
\end{abstract}

Kata Kunci: Pemilu dan Penegakan Hukum

\begin{abstract}
One measure of the success of democratic countries is seen from their success in holding elections and law enforcement. The course of law enforcement in the electoral field has undergone changes in every election both legislative elections, presidential elections and regional elections. For the current election, in following up on criminal offenses, it turns out that and not only are there different ways of working, but there is a different place of coordination than general crime. In UU No 7 Tahun 2017 it has been stipulated that there are 4 (four) institutions involved in handling cases of electoral crimes namely the Election Supervisory Committee (Panwaslu), Police, the Attorney General's, and Courts. To streamline the handling of cases of electoral violations involving criminal matters, the Election Supervisory Committee, the Police, and the Attorney General's Office form an Integrated Law Enforcement Center (Sentra Gakkumdu).
\end{abstract}

Keyword : Elections and Law enforcement 


\section{I . Pendahuluan}

Negara Indonesia merupakan Negara hukum dengan ciri-ciri sebagai Negara modern yang berbasis demokrasi dan berkedaulatan penuh oleh rakyat (Huda, 2010:225). Pemilihan Umum merupakan wujud partisipasi politik rakyat dalam sebuah negara demokrasi.Pelaksanaan pemilu yang langsung, umum, bebas, rahasia, jujur dan adil akan menjadi cerminan kualitas demokrasi. Pelaksanaan Pemilihan Umum secara langsung untuk memilih Presiden dan Wakil Presiden, Dewan Perwakilan Rakyat (DPR), Dewan Perwakilan Rakyat Daerah (DPRD), Gubernur dan Wakil Gubernur, Bupati dan Wakil Bupati, Walikota dan Wakil Walikota, merupakan salah satu agenda utama Reformasi di bidang politik.

Reformasi konstitusi dilakukan utuk menguatkan sistem politik demokratis.Pasal 2 ayat (1) Undang-Undang Dasar Negara Republik Indonesia Tahun 1945 menyatakan bahwa kedaulatan berada ditangan rakyat dan dilaksanakan menurut Undang-Undang Dasar.Makna dari "kedaulatan berada ditangan rakyat (Fahmi, 2010:124)" dalam hal ini ialah bahwa rakyat memiliki kedaulatan, tanggung jawab hak dan kewajiban untuk secara demokratis memilih pemimpinyang akanmembentuk pemerintahan. Pemerintah hasil pilihan rakyat inilah yang akan berguna mengurus dan melayani seluruh lapisan masyarakat (Rizkiyansyah, 2017:22) .Tindak Pidana Pemilu diatur pada Undang-Undang Nomor 7 Tahun 2017 diatur dalam buku kelima. Pada prinsipnya Undang-Undang ini mengatur : untuk menyamakan pemahaman dan pola penanganan tindak pidana Pemilu, dimana Bawaslu, Kepolisian Negara Republik Indonesia, dan Kejaksaan Agung Republik Indonesia membentuk suatu wadah yang disebut Sentra Penegakan Hukum Terpadu (Sentra Gakkumdu).Hal tersebut diatur oleh Undang-undang tujuannya adalah menjamin pelaksanaan Pemilu dapat berlangsung secara LUBERJURDIL.

Penyelenggara Pemilu dansemua pihak yang terlibat dalam proses pelaksanan pemilu, wajibbersikap dan bertindak jujur sesuai dengan peraturan 
perundang-udangan.Demikian pula halnya, setiap pemilih dan peserta pemiluberhak mendapat perlakuan yang sama, serta bebas dari kecurangan pihak manapun. Dalam kenyataan terjadi hal yang berbeda, masih terdapat upaya-upaya untuk mengganggu penyelenggaraan Pemilu secara langsung, umum bebas, rahasia, jujur dan adil. Tidak jarang di dalamnya terjadi tindak pidana yaitu pidana pemilu (Rizkiyansyah, 2017:38).

Tindak pidana pemilu di Indonesia dalam perkembangannyamengalami banyak perubahan baik berupa peningkatan jenis tindakpidana sampai perbedaan tentang penambahan sanksi pidana (Santoso, 2006:70). Hal inidisebabkan karena semakin hari tindak pidana pemilu semakinmenjadi perhatian yang serius. Ukuran keberhasilan Negarademokratis dilihat dari kesuksesannyamenyelenggarakan pemilu.

Penanganantindak pidana pemilu diatur spesifik dalam Undang-undang yang mengatur tentang pemilu.Untuk mengatur operasional penangan tindak pidana pemilu lebih lanjut diatur dalam Nota Kesepakatan BersamaBadan Pengawas Pemilihan Umum Republik Indonesia, Kepolisian Negara Republik Indonesia Dan Kejaksaan Republik IndonesiaNomor: 01/NKB/BAWASLU/I/2013NOMOR: B/ 2/1/2013NOMOR: KEP005/A/JA/01/ 2013TentangSentra Penegakan Hukum Terpadu.Setiap kasus kejadian tindak pidana pemilu harus diproses dengan rentang waktu yang jelas.

Terdapat rentang waktu maksimum pada setiap proses hukum tindak pidana pemilu. Batasan waktu maksimum berlaku pada proses penyelidikan, penyidikan, penyerahan berkas, perbaikan berkas, pelimpahan kepada penuntut umum, pelimpahan ke pengadilan negeri, proses sidang hingga putusan di pengadilan negeri, dan banding dengan tenggang waktu paling lama hanya 51 hari (Fahmi, 2010:124). Hal ini sangat berbeda dengan tidak pidana umum yang tidak jelas waktu penyelesaiannya. Dengan adanya keterbatasan waktu proses penyelesaian tindak pindana pemilu ini tentu membutuhkan cara kerja yang berbeda pula (Wijayanto, 2014:3). 
Dalam menindaklanjuti tindak pidana pemilu, ternyata tidak hanya cara kerja yang berbeda, namun terdapat wadah koordinasi yang berbeda dibandingkan tindak pidana umum. Dalam Undang-Undang Nomor 7 Tahun 2017 telah diaturbahwa ada 4 (empat) institusi yang terlibat dalam penanganan perkaratindak pidana pemilu yakni Panitia Pengawas Pemilu (Panwaslu),Kepolisian, Kejaksaan, dan Pengadilan.Untuk mengefektifkan penanganan perkara pelanggaran pemilu yang menyangkut pidana maka Panwaslu, Kepolisian, dan Kejaksaan membentuk Sentra Penegakan Hukum Terpadu (Sentra Gakkumdu) (Santoso, 2006:106). Berdasarkan artikel yang penulis baca, banyak pelanggaran pemilu yang akhirnya tidak memenuhi unsur pidana dan tidak dapat dilimpahkan ke pengadilan. Hal ini menyebabkan kurang efektifnya penegakan hukum yang dilaksanakan, dan yang menjadi penyebab tidak efektifnya adalah lemahnya Undang-Undang yang mengatur proses penegakan hukum serta singkatnya waktu penanganan perkara yang membuat penegak hukum kesulitan untuk melaksanakan tugasnya.

\section{Rumusan Masalah}

Oleh karena itu dalam penulisan ini terdapat dua pertanyaan yang akan dibahas, yaitu :

a. Bagaimana mekanisme penegakan hukum terhadap penanganan tindak pidana pemilu?

b. Apakah faktor-faktor yang menghambat pelaksanaan penegakan hukum terhadap penanganantindak pidana pemilu?

\section{Pembahasan}

\section{Mekanisme Penegakan Hukum Pada Penanganan Tindak Pidana Pemilu}

\section{a. Tindak Pidana Pemilu}

Mengkhusus dari pembahasan diatas maka penulis akan 
masuk pada salah satu jenis tindak pidana yang akan dibahas dalam tulisan ini, yaitu tindak pidana pemilu. Seperti kita ketahui Pemilihan Umum berlangsung setiap 5 (lima) tahun sekali dan hal itu berakibat pada aturan terkait penyelenggaraan pemilu juga berubah setiap perhelatan. Pengertian tindak pidana pemilu dalam menurut pasal 260 Undang-Undang Nomor 8 Tahun 2012, tindak pidana pemilu didefenisikan sebagai tindak pidana pelanggaran dan/atau kejahatan terhadap ketentuan tindak pidana pemilu sebagaimana diatur dalam UU Pemilu. Selain itu dalam Pemilihan Umum Kepala Daerah (Pemilukada) tahun 2018 sebagaimana dalam ketentuan dalam Undang-Undang Nomor 1 tahun 2015 sebagaimana diubah dengan Undang-Undang Nomor 8 Tahun 2015 tentang pemilihan Gubernur, Bupati dan Walikota, juga didapati pengertian yang sama yaitu "Tindak Pidana Pemilihan Umum merupakan pelanggaran atau kejahatan terhadap ketentuan pemilihan sebagai mana diatur dalam Undang-Undang ini”. Sedangkan dalam Pasal 147 Undang-Undang Nomor 7 Tahun 2017 tentang Pemilihan Umum, tidak memberikan definisi tentang tindak pidana pemilu, hanya dalam undang-undang tersebut menjabarkan tentang penanganan tindak pidana pemilu secara menyeluruh.

Berdasarkan defenisi tersebut, perbuatan/tindakan yang dapat dinilai sebagai tindak pidana pemilu adalah perbuatan yang dikriminalisasi berdasarkan Undang-Undang Pemilu. Sesuai defenisi itu, juga dapat dipahami bahwa tindak pidana pemilu adalah pelanggaran terhadap suatu kewajiban, hal mana pelanggaran tersebut diancam sanksi pidana dalam UU Pemilu (Santoso, 2006:89). Dalam Undang-Undang Nomor 8 Tahun 2012 Tentang Pemilu Anggota DPR, DPD dan DPRD tidak mendefenisikan secara spesifik apa yang dimaksud dengan "Tindak Pidana" dalam bentuk pelanggaran 
maupun kejahatan. Undang-Undang ini hanya mengatur bentukbentuk perbuatan yang dikategorikan sebagai pelanggaran dan juga kejahatan. Terkait dengan Tindak pidana pelanggaran diatur dalam Pasal 273 sampai Pasal 291 UU Nomor 8 Tahun 2012, yang mana terhadap Pelanggaran tindak pidana Pemilu diancam dengan pidana kurungan paling lama 1 (satu) Tahun dan dikenakan Denda paling banyak Rp. 12.000.000,- (dua belas juta rupiah), sedangkan untuk tindak pidana kejahatan diatur dalam Pasal 292 - Pasal 321 UndangUndang Nomor 8 Tahun 2012, dan terhadap Kejahatan tindak pidana Pemilu diancam dengan pidana penjara rata-rata antara 2 (tahun ) Tahun sampai dengan 4 (empat) Tahun dan dikenakan Denda rata-rata Rp. 36.000.000,- (tiga puluh enam juta rupiah rupiah).

\section{Tata cara penanganan tindak pidana pemilu menurut Nota Kesepahaman antara Bawaslu, Kepolisian, dan Kejaksaan RI}

Penyelenggaraan Pemilu yang berlangsung tahap demi tahap, setiap tahapannya berpotensi terjadi tindak pidana. Tindak pidana dapat saja dilakukan oleh peserta Pemilu, anggota masyarakat pemilih bahkan oleh penyelenggara Pemilu itu sendiri. Dalam Ketentuan Umum Undang-Undang Pemilu dijelaskan tentang Bawaslu sebagai lembaga penyelenggara Pemilu yang bertugas mengawasi, memediasi perselisihan dan mengadili dalam proses ajudikasi penyelenggaraan Pemilu di seluruh wilayah Negara Kesatuan Republik Indonesia. Dalam pelaksanaan tugasnya, Bawaslu membentuk Badan Pengawas Pemilu (Pawaslu) Provinsi yang bertugas mengawasi memediasi perselisihan dan mengadili dalam proses ajudikasi penyelenggaraan Pemilu di provinsi. Selanjutnya Badan Pengawas Pemilu Provinsi membentuk Panitia Pengawas Pemilu (Panwaslu) Kabupaten/Kota yang bertugas mengawasi memediasi perselisihan dan mengadili dalam 
proses ajudikasi penyelenggaraan Pemilu di kabupaten/kota. Demikian seterusnya secara berjenjang dibentuk panitia pengawas yang bersifat adhoc sampai ke tingkat Tempat Pemungutan Suara (TPS). Lembaga pengawasan adhoc

Salah satu langkah strategis sinergisitas antar lembaga penegak hukum agar tidak ada lagi perbedaan persepsi dalam melakukan penanganan pelanggaran pidana Pemilu maka dibentuklah wadah Sentra Gakkumdumelalui penandatanganan Nota Kesepakatan Bersama (MOU) antara Badan Pengawas Pemilu RI, Kepolisian Negara RI dan Kejaksaan RI.Maksud dari nota kesepahaman antara tiga lembaga tersebut tidak sekedar untuk menyamakan pemahaman (menyamakan persepsi),tetapi juga untuk menyamakanpola penanganan tindak pidana Pemilu secara terpadu dan terkoordinasi antara Bawaslu, Polri dan Kejaksaan. Gakkumdu juga merupakan mekanisme untuk mewujudkan kerjasama dan sinergisme dalam rangka Penegakan Hukum Terpadu, serta tercapainya penegakan hukum Tindak Pidana Pemilu secara cepat dan sederhana, serta tidak memihak.

Proses penanganan dan penyelesaian tindak pidana Pemilu mengacu pada Standar Operasional Prosedur (SOP) Sentra Gakumdu seperti diuraikan di bawah ini.

1) Proses Penerimaan Laporan

a. Laporan yang diduga mengandung unsur dugaan tindak pidana Pemilu diterima oleh Panwas Pemilu dengan menggunakan Formulir yang diatur dalam Peraturan Bawaslu Tentang Tata Cara Penerimaan Laporan dan Penanganan Pelanggaran;

b. Temuan hasil Pengawas Pemilu yang diduga mengandung unsur dugaan tindak pidana pemilu diteruskan kepada bidang penindakan Pelanggaran dengan menggunakan Formulir yang diatur dalam Peraturan Bawaslu Tentang Tata Cara Penerimaan Laporan dan Penanganan Pelanggaran; 
c. Pengawas Pemilu menyampaikan temuannya atau laporan sebagai dimaksud huruf a dan dan huruf b kepada Sentra Gakumdu pada hari yang sama saat menerima laporan atau penerusan tersebut :

- Pengawas Pemilu menyampaikan temuan atau laporan kepada Ketua Sentra Gakumdu dengan menggunakan Formulir SG-1 yang dilampiri dengan Formulir Laporan atau Temuan dugaan Tindak Pidana Pemilu;

- Formulir SG-1 memuat penyampaian adanya laporan atau temuan sekaligus sebagai undangan kepada Ketua dan Anggota Sentra Gakkumdu untuk membahas laporan atau temuan tersebut;

- Dalam rangka efisiensi dan evektivitas setelah menerima laporan atau temuan dugaan Tindak Pidana Pemilu, disamping melakukan kegiatan sebagaimana tersebut diatas, Pengawas Pemilu segera berkoordinasi dengan Anggota Sentra Gakkumdu dengan cara berkomunikasi melalui media komunikasi yang ada (misalnya telepon/SMS dll);

2) Pembahasan Sentra Gakumdu;

a. Dalam setiap pembahasan Sentra Gakkumdu, Pengawas Pemilu bertugas sebagai pimpinan di Sentra Gakkumdu;

b. Pimpinan membuka pembahasan dan menyampaikan materi laporan atau temuan dugaan Tindak Pidana Pemilu;

c. Hasil pembahasanSentra Gakkumdu dituangkan dalam Berita Acara Pembahasan Sentra Gakkumdu;

d. Kesimpulan Sentra Gakkumdu dapat berupa :

- Laporan atau temuan bukan merupakan Tindak Pidana Pemilu;

- Laporan atau temuan merupakan Tindak Pidana Pemilu; 
- Laporan atau temuan merupakan Tindak Pidana Pemilu, akan tetapi masih perlu untuk dilengkapi pemenuhan syarat formil dan/atau materiil;

\section{Alur Penanganan Tindak Pidana Pemilu Menurut Undang-undang No Undang-Undang No 7 Tahun 2017.}

Penanganan tindak pidana pemilu mengikuti sistem peradilan pidana secara umum. Sistem penegakan hukum yang terdiri dari kepolisian, kejaksaan, pengadilan dan lembaga pemasyarakatan terlibat dalam satu jaringan kerja yang saling berkaitan satu sama lain. Dalam hukum pidana pemilu, sistem kerja demikian juga berlaku. Hanya saja, terdapat sejumlah aturan khusus yang terdapat dalam hukum pidana pemilu.

Pertama, dari segi hukum materil yang digunakan, tindak pidana pemilu diatur secara khusus dalam UU Pemilu dan UU Pilkada. Dalam arti, berbagai perbuatan yang ditetapkan sebagai tindak pidana pemilu hanya dapat dituntut sesuai UU Pemilu, bukan ketentuan pidana umum. Hal ini sesuai dengan penerapan asas lex specialis derogat legi gerali. Menurut asas ini, semua unsur-unsur suatu rumusan delik terdapat atau ditemukan kembali di dalam peraturan lain, sedangkan peraturan yang disebut kedua (yang khusus) itu disamping semua unsur-unsur peraturan pertama (yang umum) memuat pula satu atau beberapa unsur lain.

Kedua, dari aspek hukum formil, hukum pidana pemilu juga tunduk pada ketentuan yang berlaku dalam Kitab Undang-Undang Hukum Acara Pidana (KUHAP). Di mana, pengadilan negeri dalam memeriksa, mengadili, dan memutus perkara tindak pidana pemilu menggunakan KUHAP, kecuali ditentukan lain dalam UU Pemilu. Salah satu kekhususan dalam penanganan tindak pidana pemilu adalah sangat terbatasnya waktu penyidikan, penuntutan dan pemeriksaan oleh pengadilan. Pembatasan waktu dalam memeriksa dan mengadili tindak pidana pemilu sesungguhnya ditujukan agar 
dalam penanganan tindak pidana pemilu dapat memberikan kepastian hukum bagi tahapan penyelenggaraan pemilu. Selain itu, kekhususan tindak pidana pemilu juga terlihat pada keterbatasan upaya hukum bagi orang yang dinyatakan terbukti melakukan tindak pidana pemilu. Di mana, terhadap putusan pengadilan hanya dapat dilakukan banding dan putusan pengadilan banding (Pengadilan Tinggi) memiliki sifat terakhir dan mengikat serta tidak dapat dilakukan upaya hukum lain. Dengan demikian, upaya kasasi sebagai upaya hukum biasa tidak tersedia dalam pemeriksaan tindak pidana pemilu.

Ketiga, penegakan hukum pidana pemilu juga melibatkan institusi penyelenggara pemilu, dalam hal ini Bawaslu dan jajarannya. Penyidikan terhadap dugaan tindak pidana pemilu terlebih dahulu harus dengan adanya laporan/ rekomendasi dari Bawaslu Provinsi dan Bawaslu Kabupaten/kota. Sentra Gakumdu ini berkedudukan sebagai tempat untuk menyamakan pandangan antar institusi yang terlibat dalam menangani tindak pidana pemilu. Dalam pengaturan teknis dan praktiknya, Gakkumdu justru ditempatkan sebagai institusi yang bertugas menyelenggarakan penanganan tindak pidana pemilu secara terpadu. Pada saat yang sama, juga memberi penilaian apakah bukti-bukti dugaan tindak pidana Pemilu yang diserahkan Bawaslu beserta jajaran telah terpenuhi atau setidak.

Keempat, pemeriksaan perkara tindak pidana ditangani oleh majelis khusus yang dibentuk pada pengadilan negeri maupun pengadilan tinggi. Hakim khusus perkara pidana pemilu mesti memiliki syarat dan kualifikasi tertentu yang pengangkatannya ditetapkan berdasarkan Keputusan Ketua Mahkamah Agung Republik Indonesia.

Kelima, pelaporan terhadap kejadian tindak pidana pemilu dilakukan paling lama 7 (tujuh) hari setelah diketahui terjadinya tindak pidana Pemilu (Pasal 454 ayat 6). 
Lima hal itulah yang menunjukan kekhususan sistem peradilan pidana pemilu yang diatur dalam UU Pemilihan Umum.Penulis akan menguraikan satu persatu prosedur penanganan perkara daritemuan maupun laporan diterima hingga eksekusi.

Alur penanganan dan penyelesaian tindak pidana pemilu berdasarkan Undang-Undang No 7 Tahun 2017 Tentang Pemilihan Umum, seperti penulis tampilkan dalam bentuk skema di bawah ini.

Skema 1.

Alur Penanganan Dan Penyelesaian Tindak Pidana Pemilu Menurut Undang-Undang No 7 Tahun 2017.

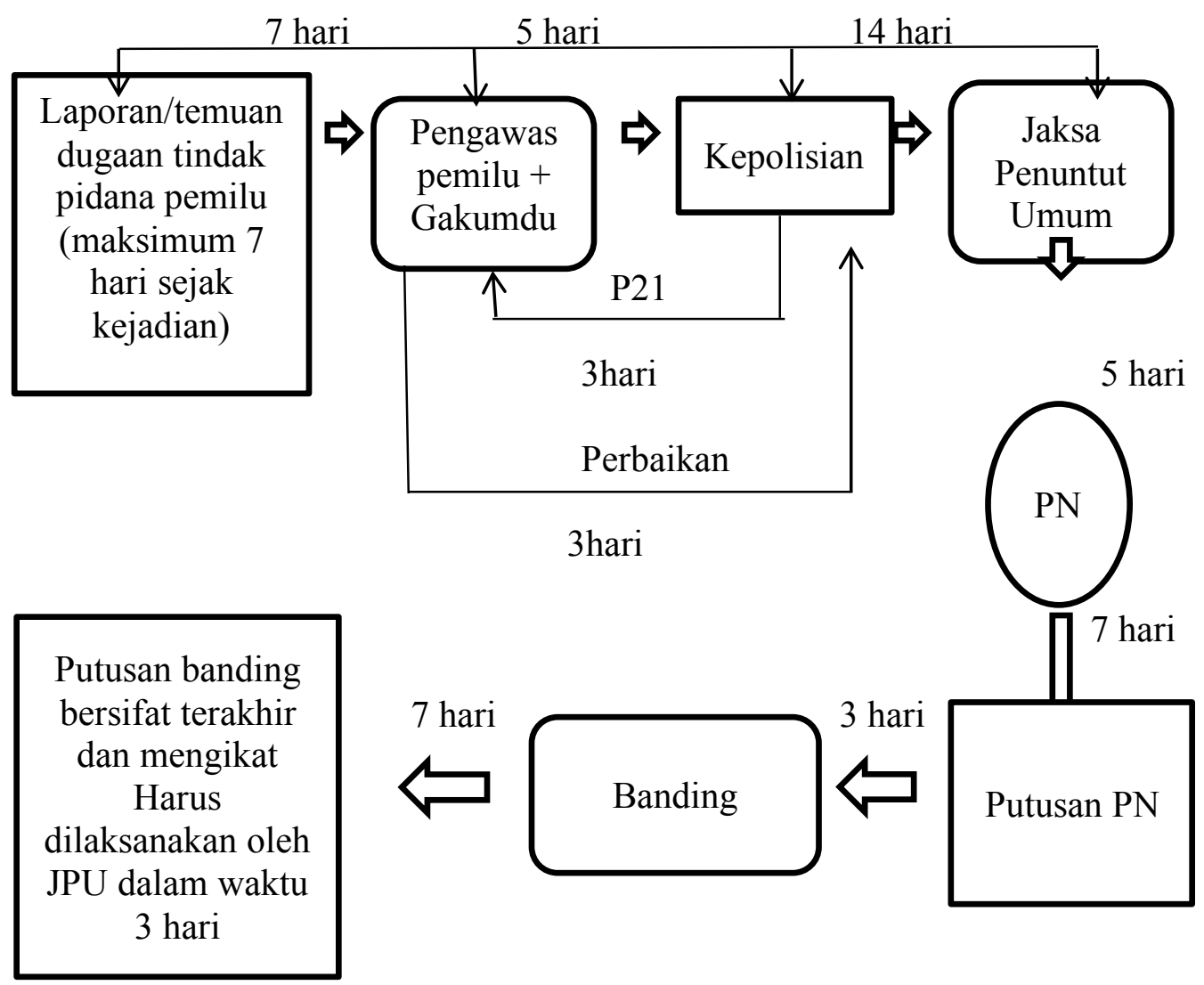

Penulis akan menjabarkan bagaimana ketentuan dalam Undang-undang No 7 Tahun 2017, terkait penanganan perkaranya secara umum sama, yaitu :

a.1 Penyidikan dan Prapenuntutan : sebagaimana ketentuan Pasal 480 
Undang-undang No.7 Tahun 2017, maka saat proses penyidikan Penyidik menyampaikan hasil penyidikannya disertai berkas perkara kepada penuntut umum paling lama 14 (empat belas) hari sejak diterimanya laporan. Dalam hal hasil penyidikan belum lengkap, dalam waktu paling lama 3 (tiga) hari penuntut umum mengembalikan berkas perkara kepada Penyidik disertai petunjuk tentang hal yang harus dilakukan untuk dilengkapi. Selanjutnya Penyidik dalam waktu paling lama 3 (tiga) hari sejak tanggal penerimaan berkas harus sudah menyampaikan kembali berkas perkara tersebut kepada penuntut umum. Penuntut umum melimpahkan berkas perkara kepada pengadilan negeri paling lama 5 (lima) hari sejak menerima berkas perkara.

a.2 Penuntutan : Pengadilan negeri dalam memeriksa, mengadili, dan memutus perkara tindak pidana Pemilu yang diulakukan oleh Majelis Khusus menggunakan Kitab Undang-Undang Hukum Acara Pidana, kecuali ditentukan lain dalam UUNo. 7 Tahun 2017, diantaranya pada pasal 481 dan Pasal 482, Undang-Undang No.7 Tahun 2017 Tentang Pemilihan:

(1) Pengadilan negeri memeriksa, mengadili, dan memutus perkara tindak pidana Pemilu paling lama 7 (tujuh) hari setelah pelimpahan berkas perkara;

(2) Jika ada upaya banding, permohonan banding diajukan paling lama 3 (tiga) hari setelah putusan dibacakan.

(3) Pengadilan negeri melimpahkan berkas perkara permohonan banding kepada pengadilan tinggi paling lama 3 (tiga) hari setelah permohonan banding diterima.

(4) Pengadilan tinggi memeriksa dan memutus perkara banding paling lama 7 (tujuh) hari setelah permohonan banding diterima. 
(5) Putusan pengadilan tinggi merupakan putusan terakhir dan mengikat serta tidak dapat dilakukan upaya hukum lain.

Putusan yang terkait dengan angka (1) dan angka (4) di atas, yang mempengaruhi hasil pemilu secara nasional, tidak boleh melampaui ketentuan Undang-Undang 7 Tahun 2017 Pasal 484 ayat (1) yang berbunyi : Putusan pengadilan terhadap kasus tindak pidana Pemilu yang menurut Undang-Undang ini dapat memengaruhi perolehan suara Peserta Pemilu harus sudah selesai paling lama 5 (lima) hari sebelum KPU menetapkan hasil Pemilusecara nasional.

a.3 Eksekusi : Putusan pengadilan yang telah berkekuatan hukum tetap (putusan akhir) harus sudah disampaikan kepada penuntut umum paling lambat 3 (tiga) hari setelah putusan dibacakan.Putusan pengadilan tersebut harus dilaksanakan paling lambat 3 (tiga) hari setelah putusan diterima oleh jaksa.

\section{Faktor Penghambat Penegakan Hukum Terhadap Penanganan Tindak Pidana Pemilu}

\section{a. Faktor penghambat dalam penanganan tindak pidana pemilu}

Penegakan hukum tidak serta merta dapat dilakukan dengan lancar tanpa hambatan atau halangan, Penegakan hukum adalah sebuah proses yang melibatkan banyak pihak sehingga untuk menyamakan persepsi para pihak serta masyarakat sebagai pihak yang menerima penerapan hukum itu pasti ada hambatan yang akan dihadapi. Hambatan penegakan hukum pidana pemilu setidaknya dapat dinilai dengan melihat masing-masing komponen dalam sistem hukum yang secara langsung berpengaruh terhadap penegakan hukum. Lawrence $M$. Friedman menilai, berhasil atau tidaknya hukum ditegakkan tergantung pada tiga komponen sistem hukum,yaitu (Ali, 2005:1): 
1) Pertama, substansi hukum (legal substance). Substansi hukum adalah aturan, norma, dan pola prilaku nyata manusia yang berada dalam sistem itu.

2) Kedua, struktur hukum (legal structure) atau struktur sistem hukum. Friedman menyebutnya sebagai kerangka atau rangka atau bagian yang tetap bertahan atau bagian yang memberi semacam bentuk dan batasan terhadap keseluruhan.Keberadaan struktur hukum sangat penting, karena betapapun bagusnya norma hukum, namun jika tidak ditopang aparat penegak hukum yang baik, penegakan hukum dan keadilan hanya sia-sia.

3) Ketiga, budaya hukum(legal culture). Kultur hukum adalah opiniopini, kepercayaan-kepercayaan (keyakinan-keyakinan), kebiasaankebisaaan, cara berfikir, dan cara bertindak, baik dari para penegak hukum maupun dari warga masyarakat tentang hukum dan berbagai fenomena yang berkaitan dengan hukum.

Berangkat dari tiga indikator tersebut, belum efektifnya penegakan hukum pidana pemilu juga tidak dapat dilepaskan dari masalah yang terdapat dalam peraturan perundang-undangan pemilu, khususnya terkait tindak pidana pemilu (Fahmi, 2015). Masalah profesionalisme aparat penegakan Hukum Yang Terdiri Dari Pengawas Pemilu, Kepolisian, Kejaksanaan dan Hakim pada Pengadilan Negeri dan Pengadilan Tinggi, dan budaya hukum penyelenggaraan pemilu yang masih belum berjalan dengan baik.

\section{Faktor Substansi}

Pada taraf norma, peraturan perundang-undangan sebagaimana diuraikan Undang-Undang Nomor 7 Tahun 2017 Tentang Pemilihan Umum, dengan substansi aturan yang sama sudah cukup jelas dan mengatur hukum materil maupun hukum formil. Sementara pada bagian struktur, penegak hukum dihadapkan pada persoalan masih belum 
memadainya pemahaman aparatur terhadap jenis tindak pidana pemilu, belum profesional dan masih terjadinya "tolakmenolak" yang berujung pada kebuntuan dalam menangani perkara pidana pemilu. Sedangkan pada ranah budaya hukum, pihak-pihak berkepentingan, terutama peserta pemilu masih berkecenderungan untuk memanipulasi aturan yang ada sehingga dapat berkelit dari tuntutan hukum. Masyarakat bukannya membangun kesadaran akan perlunya mengikuti pemilu sesuai aturanaturan yang ada, melainkan justru membangun sikap kurang empati atas aturan yang ada.

Persoalan penegakan hukum pidana pemilu tersebut terjadi sedemikian rupa sehingga penegakan hukum pemilu tidak dapat berjalan secara efektif dan maksimal.Akibatnya, perkara-perkara dugaan tindak pidana pemilu pun tidak dapat ditangani. Disisi penyidikan, total waktu selama 20 (dua puluh) hari (termasuk perpanjangan/perbaikan berkas) sangat susah untuk mendapatkan bukti-bukti yang diharapkan untuk diajukan dalam persidangan. Selain itu dapat dibayangkan dengan volume/ kuantitas jumlah perkara yang masuk sangat banyak juga mempengaruhi proses penyidikan karena jumlah perkara yang banyak tetap saja diselesaikan dalam waktu 20 (dua puluh) hari penyidikan. Sedangkan disisi Penuntutan juga dihadapkan dengan waktu pelimpahan yang hanya 5 (lima) hari untuk mempersiapkan segala bukti-bukti yang akan dihadirkan dalam persidangan. Begitu juga disisi persidangan diharuskan 7 (tujuh) hari harus sudah diputus dengan dinamika banyaknya saksi yang dihadirkan dalam persidangan.

\section{Faktor Penegak Hukum Tindak Pidana Pemilu.}

Memang dalam penanganan perkara tindak pidana Pemilu, telah ada Sentra gakkumdu sebagai wadah komunikasi antara pihak Panwaslu selaku pengawas pemilu, Polri selaku penyelidik dan penyidik sertaJaksa selaku Jaksa Penuntut Umum guna memaksimalkan upaya 
penegakan hukum.Keberadaan Sentra gakkumdu belum mampu memberi bahwa jaminan proses penegakan hukum berjalan dengan baik tanpa hambatan.

\section{Faktor Budaya Hukum.}

Faktor budaya hukum disini bisa penulis jabarkan yaitu faktor budaya hukum masyarakat dan tersangka. Kendala-kendala lain yang dihadapi oleh penegak hukum yaitu rendahnya kesadaran hukum masyarakat. Kurangnya kesadaran masyarakat akan pentingnya hukum untuk ditaati, dan lebih mementingkan kepentingan pribadi dari pada kepentingan umum. Perilaku serta kesadaran warga masih rendah dalam mentaati aturan dalam Pemilihan Umum. Masyarakat sendiri merasa perilaku melanggar peraturan perundang-undangan Pemilu yang dapat dikategorikan tindak pidana Pemilu adalah perilaku yang tidak begitu meresahkan, padahal perbuatan mereka dapat mempengaruhi perhitungan perolehan suara peserta Pemilu serta mencedrai demokrasi. Masyarakat yang acuh takacuh dalam penegakan hukum pelanggaran tindak pidana Pemilu, juga melihat peluang untuk menghindar dari jeratan hukum dimana mereka bermain dengan batasan waktu penanganan perkara. Permaina ini mengakibatkan penangan perkara tidak dapat dilanjutkan dikarenakan telah habis masa penanganannya secara formil.

\section{Upaya Menanggulangi Faktor Penghambat didalam melaksanakan penegakan hukum terkait penanganan dugaan tindak pidana pemilu}

Proses penegakan hukum selalu akan menghadapi berbagai dinamika, dari sekian banyak penghambat dalam penegakan hukum tindak pidana pemilu sebagaimana ketentuan dalam UU No 7 Thaun 2017 Tentang Pemilu, maka penulis telah mendapatkan beberapa gambaran terkait caracara yang dapat dilakukan guna menanggulangi kendala dalam penegakan hukum tindak pidana pemilu, diantaranya : 
Pertama, dengan kekhususan Undang-Undang Nomor 7 Tahun 2017 tentang Pemilihan Umum terkait dengan waktu penanganan perkara yang sangat singkat maka secara nasional penegak hukum dalam hal ini Panwaslu, Polri, dan Kejaksaan RI, membentuk suatu wadah yaitu Sentra Penegakan Hukum Terpadu (Sentra Gakkumdu) yang merupakan forum bersama yang berdasarkan dalam Nota Kesepakatan Bersama Bawaslu RI, POLRI, dan Kejaksaan RI No. Kep/005/A/Ja/01/2013 juga diatur Sentra Penegakan Hukum Terpadu tentang Pemilihan Presiden dan Wakil Presiden.Dengan adanya sentra gakkumdu ini merupakan langkah awal untuk mencegah faktor-faktor yang dapat menghambat penegakan hukum pidana pemilu, karena Sentra Gakkumdu sifatnya merupakan forum bersama yang bersifat komunikatif semenjak adanya indikasi pelanggaran pidana pemilu.Adapun maksud dan tujuan dibentuknya Sentra Gakkumdu itu sendiri adalah (Kejaksaan Republik Indonesia, 2019:143):

Maksud :

1) Memastikan penanganan Tindak Pidana Pemilu terlaksana secara efisien dan efektif, konsisten, standar dan sistematis;

2) Adanya sinergisme antara Pengawas pemilu, Kepolisian Negara Republik Indonesia, dan Kejaksaan Republik Indonesia dalam penanganan Tindak Pidana Pemilu;

Tujuan :

1) Tercapainya sinergisme penanganan tindak pidana pemilu antara Pengawas pemilu, Kepolisian Negara Republik Indonesia, dan Kejaksaan Republik Indonesia;

2) Sebagai pedoman bagi Pengawas pemilu, Kepolisian Negara Republik Indonesia, dan Kejaksaan Republik Indonesia dalam rangka penyamaan pemahaman dan pola penanganan Tindak Pidana Pemilu;

3) Terlaksananya penanganan Tindak Pidana Pemilu secara efisien dan efektif, konsisten, standar dan sistematis. 
Kedua, dari dalam Panwaslu sendiri telah melakukan beberapa hal guna menanggulangi hambatan dalam praktek pelaksanaan. Seperti halnya ketika ada laporan terkait pelanggaran pemilu, maka Pengawas Pemilu akan sesegera mungkin melaksanakan kajian. Berdasarkan kajian tersebut akan diputuskan suatu tindakan tersebut masuk tindak pidana atau bukan. Tindak yang mememuhi unsur tindak pidana Pemilu selanjutnya dibuatkan laporan kepada Kepolisian.

Penyidik dalam menganggulangi hambatan yaitu dengan sesegera mungkin melaksanakan tugas-tugasnya setelah masuknya laporan dari bawaslu/panwaslu seperti penyitaan, penggeledahan, serta mengamankan saksi-saksi yang terkait untuk mendapatkan bukti sebanyak-banyaknya. Kini untuk menyongsong Pilkada 2018 dan Pemilu 2019, pihak Kepolisan telah bersiap dengan melakukan penataan dan peningkatan kinerja Polri secara profesional dengan mendasarkan pada kultur maupun tata kehidupan masyarakat Indonesia serta sistem hukum nasional. Seperti yang ditegaskan oleh Kapolri Jend. Titio Karnavian "Sikap Netralitas Polri Menyambut Pilkada 2018 dan Pemilu 2019" bahwa (Sacipto, 2018:374):

1. Anggota Polri dilarang mendeklarasikan diri sebagai bakal calon;

2. Dilarang menerima atau meminta hadiah;

3. Dilarang menghadiri atau menjadi pembicara, dan narasumber kegiatan politik;

4. Dilarang mempromosikan dan menyebarluaskan atribut partai atau calon;

5. Dilarang memberikan dukungan politik dalam bentuk apapun;

6. Dilarang jadi pengurus atau anggota tim sukses pasangan calon; 
7. Dilarang menggunakan kewenangan atau membuat keputusan politik;

8. Dilarang memberikan fasilitas dinas maupun pribadi dan melakukan black campaign;

9. Dilarang memberikan informasi kepada siapapun.

Keempat,Upaya yang dilakukan Jaksa Penuntut Umum adalah selalu melaksanakan koordinasi dengan Panwaslu dan Kepolisian guna lancarnya jalan persidangan sejak pertama kali laporan atau temuan diterima pihak Panwas. Kegunaan koordinasi itu membantu pihak panwaslu dan Polisi Penyidik untuk mencari bukti-bukti yang akan digunakan dalam persidangan sehingga diharapkan dengan telibatnya Jaksa dari awal Temuan atau Laporan maka hal tersebut dapat mencegah bolak baliknya perkara di tingkat Prapenuntutan. Sedangkan di tingkat Penuntutan atau persidangan, pihak Penuntut Umum tetap berkoordinasi dengan Panwas dan Penyidik guna melancarkan jalannya persidangan. Sistem kerja antara Panwaslu, Kepolisian dan Kejaksaan dalam Sentra Gakkumdu sekarang ini telah baik dalam satu atap. Karena Sentra Gakkumdu merupakan satu kesatuan, sehingga berhasil tidaknya penangan perkara adalah dibawah komando Sentra Gakkumdu yang mana diharapkan penyelesaian perkara Pemilu dapat berlangsung cepat, sederhana dan biaya murah.

\section{Kesimpulan}

Berdasarkan pemaparan diatas maka dapat diambil simpulan atas rumusan masalah yaitu sebagai berikut :

1. Mekanisme penegakan hukum terhadap penanganan dugaan tindak pidana Pemilu memiliki beberapa kekhususan ditinjau dari sisi lembaga, 
waktu, dan mekanisme. Kekhususan ditinjau dari sisi waktu yang dipergunakan untuk menangani tindak pidana pemilu adalah sebagai berikut : (a) Dimulai dari adanya laporan dari masyarakat atau temuan oleh Pengawas Pemilu yang kemudian dikaji keterpenuhannya atas unsur tindak pidana Pemilu, Jika memenuhi unsur, maka berkas tindak pidana akan diserahkan pada kepolisian dengan waktu paling lama 5 hari untuk selanjutnya dilakukan penyidikan; (b) Kepolisian menyerahkan berkas hasil penyidikan selama paling lama 14 hari kepada Jaksa Penuntut Umum terhitung dari diserahkannya berkas tindak pidana guna melaksanakan penyidikan, mengumpulkan buktibukti dan membuat berkas perkara; (c) Berkas perkara yang sudah rampung kemudian dilimpahkan pada Jaksa Penuntut Umum yang merupakan dasar bagi penuntut umum untuk membuat surat dakwaan; (d) Sebelum membuat surat dakwaan, penuntut umum melaksanakan pra penuntutan terlebih dahulu dengan tujuan mengkaji kelengkapan berkas perkara; (e) surat dakwaan yang sudah rampung akan segera dilimpahkan pada Pengadilan Negeri paling lama 5 hari; (f) Pengadilan Negeri dalam memeriksa, mengadili, dan memutus perkara pidana pemilu berpedoman kepada UU Pemilu paling lama 7 hari dengan sidang yang dilaksanakan terbuka untuk umum.

2. Faktor-faktor yang menjadi kendala dalam proses penegakan hukum didalam penyelenggaraan pemilu adalah

a. Faktor Substansi (UU/Aturan)

Penyidik dan Jaksa Penuntut Umum sendiri mengakui dengan batasan waktu penanganan perkara yang singkat, sangat mempengaruhi kualitas pembuktian dalam persidangan. Kelemahan Undang-undang adalah dari segi ancaman hukumannya, yang berakibat tidak dapat dilakukan penahanan kepada para pelaku, 
karena rata-rata diancam dibawah 5 (lima) Tahun, sehingga mempersulit proses penyidikan.

b. Faktor penegak hukum

Terjadi perbedaan pandangan antara pihak Pengawas Pemilu Kabupaten Badung dengan penyidik.Terkadang pihak panwas merasa perkara sudah layak dijadikan atau ditingkatkan statusnya ke tahap penyidikan, namun Penyidik dan Jaksa menganggap peristiwa yang terjadi tidak termasuk dalam ranah Tindak Pidana Pemilu.Perbedaan pemahaman tentang pembuktian antara Panwas dengan Penyidik maupun Penuntut.Kurangnya pemahaman terkait alat bukti yang dibutuhkan didalam melakukan kajian mengakibatkan beberapa tindakan yang diduga merupakan tindak pidana Pemilu hanya berakhir di Panwaslu, tidak sampai ke kepolisian.

c. Faktor Budaya Hukum

Pertama, rendahnya kesadaran hukum masyarakat. Kurangnya kesadaran masyarakat akan pentingnya hukum untuk ditaati, dan lebih mementingkan kepentingan pribadi dari pada kepentingan umum. Perilaku serta kesadaran warga sangat rendah dalam mentaati aturan dalam Pemilihan Umum.Masyarakat sendiri merasa melakukan tindak pidana Pemilu tidak begitu meresahkan, padahal perbuatan mereka dapat mempengaruhi perhitungan perolehan suara dan kualitas demokrasi. 


\section{Daftar Pustaka}

\section{Buku :}

Ali, Achmad. Keterpurukan Hukum di Indonesia Penyebab dan Solusinya.Bogor: Ghalia Indonesia.

Arief, Barda Namawi. 2005. Bunga Rampai Kebijakan Hukum Pidana, Bandung : Kencana Prenada.

Huda, Ni Matul. 2010. Hukum Tata Negara. Jakarta: PT.Raja Grafido Persada, Jakarta, Cetakan ke-5.

Jurdi, Fajlurahman. 2018. Pengantar Hukum Pemilihan Umum. Jakarta : Prenada Media Group.

Kejaksaan Republik Indonesia, 2019, Buku Pedoman Penanganan Perkara Tindak Pidana pemilihan Umum Tahun 2019, Jakarta.

Rahardjo, Satjipto.2002. Sosiologi Hukum Perkembangan Metode dan Pilihan Masalah.penyunting Khudzaifah Dimyati, Surakarta : Muhammadiyah University Press.

Raharjo, Satjipto. 2009. Penegakan Hukum Sebagai Tinjauan Sosiologis. Yogyakarta : Genta Publishing.

Rizkiyansyah, Ferry Kurnia. 2014. Pemilu dan Demokrasi Terkonsolidasi, Catatan Penyelenggaraan Pemilu. Jakarta : PT. Epicentrum Mahadaya Komunika.

Santoso, Topo . 2006. Tindak Pidana Pemilu. Jakarta :Sinar Grafika, Cetakan Pertama.

Santoso, Topo dkk.2006.Penegakan Hukum Pemilu, Praktik Pemilu 2004, Kajian Pemilu 2009-2014, Jakarta : Perkumpulan Untuk Pemilu dan Demokrasi.

\section{Jurnal :}

Khairul Fahmi. 2010. Prinsip Kedaulatan Rakyat Dalam Penentuan Sistem Pemilihan Umum Anggota Legislatif, Jurnal Konstitusi, volume 7, nomor 3, Juni. 
Khairul Fahmi, Sistem Penanganan Tindak Pidana Pemilu, Pusat Studi Konstitusi, Fakultas Hukum Universitas Andalas, Vol. 12, No. 2 Juni 2015.

Rian Sucipto, Eksistensi Polri dalam Penegakan Hukum Tindak Pidana Pemilu Menyongsong Pesta Demokrasi Indonesia 2019, Seminar Nasional Hukum Universitas Negeri Semarang Volume 4 Nomor 2 Tahun 2018.

\section{Undang-Undang :}

Undang-Undang Nomor 8 Tahun 2012 Tentang Pemilihan Umum Anggota DPR, DPD, DPRD

Undang-Undang Nomor 7 Tahun 2017 Tentang Pemilihan Umum

Undang-Undang Nomor 15 Tahun 2011 Tentang "Penyelenggaraan Pemilihan Umum 